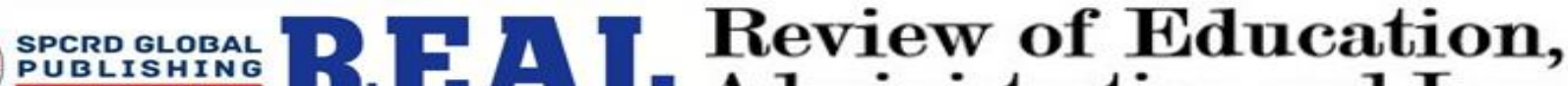 Sustainable Solutions 10 Administration and LaW \\ Journal homepage: http://real.spcrd.org ISSN (Print): 2708-1788 \\ ISSN (Online): 2708-3667
}

\section{Socio-Economic Peripherals of women's Assistance to Family Sustenance: A Primary Data Analysis}

\footnotetext{
${ }^{\text {a }}$ Rashid Ahmad, ${ }^{\mathrm{b}}$ Muhammad Zahir Faridi, ${ }^{\mathrm{c}}$ Furrukh Bashir, ${ }^{\mathrm{d}}$ Shan-E-Zahra

${ }^{a}$ Assistant Professor, School of Economics, Bahauddin Zakariya University, Multan, Pakistan

Email: rashidahmad@bzu.edu.pk

${ }^{\mathrm{b}}$ Professor, School of Economics, Bahauddin Zakariya University, Multan, Pakistan

Email: zahirfaridi@bzu.edu.pk

${ }^{c}$ Assistant Professor, School of Economics, Bahauddin Zakariya University, Multan, Pakistan

Email: furrukh@bzu.edu.pk

${ }^{\mathrm{d}}$ M.Phil Scholar, School of Economics, Bahauddin Zakariya University, Multan, Pakistan

Email: shanezehra717@gmail.com
}

\begin{tabular}{ll}
\hline ARTICLE DETAILS & ABSTRACT \\
\hline History: & $\begin{array}{l}\text { The present study explores the factors that determine the women's } \\
\text { Accepted 13 March } 2021\end{array}$ \\
contribution in family budget. Primary source of data are used for \\
analysis. Four hundred women are interviewed. Three models are \\
constructed for investigating women's contribution in family income. \\
Keywords: & $\begin{array}{l}\text { Ordinary least squares technique is employed for analysis. The study } \\
\text { concludes that women's age, education, marital status, household size, }\end{array}$ \\
Women's Contribution, Healthy 2021 & healthy diet outside work permission and number of children are \\
Least Squares, Pakistan & significantly contributing in household budget. It is suggested that \\
& responsible authorities should provide the educational facilities specially \\
for females. Awareness for family planning and best health facilities & should be given to the women.
\end{tabular}

DOI: $10.47067 /$ real.v4i1.129

(C) 2021 The authors. Published by SPCRD Global Publishing. This is an open access article under the Creative Commons AttributionNonCommercial 4.0

Corresponding author's email address: zahirfaridi@bzu.edu.pk

\section{Introduction}

Pakistan is a leading country in the list of underdeveloped economies. The total population of Pakistan is almost $220,892,340$ (2020). The population growth rate is 2.00 percent per annum that is still very high. Almost more than half of the population consists of females. In Pakistan, the female labour force participation rate is $\mathbf{1 1 . 5 0}$ that is very low as compared to developed and many underdeveloped countries. The dependency burden is very high. Women's labour force participation has become a crucial issue in order to share the family's expenditure burden. Changing world scenario and advancement of technology, comforts and luxuries have become necessities of life. It has become very difficult to burn both ends with sole earner. Both life partner work participation has become an imperative.

According to G.Becker (1962) and Jcob Mincre (1974), Health and Education has direct and 
positive influence on the women's life time earnings. But generally in developing economies and especially in Pakistan, health related issues and low level of education are the main obstacles for women's work participation. However, many studies explain that various levels of education raise the workers efficiency, skills and returns [Gaag and Vijnerberg (1989); Khandlber (1990); Schultz and Mwabu (1998)]. Generally, it is observed that less recognition is given to female as compared to male and many socio-economic constraints are imposed on women's work participation. The women's activities are restricted to inside home. Gender discrimination is another obstacle for work participation. Moreover, in less developed countries, women's life span is very low because of imbalanced provision of health facilities. Women's life expectancy is very short in poor countries because quality and access to health services are unequal [Tinker (2000)].

Developing economies like Pakistan are not only confronting with the issue of poverty but also facing the issues like high Unemployment, low GDP Growth Rate, High Inflation and misallocation or maldistribution of resources with financial constraints. These issues may be tackled by enhancing labour force participation especially female in order to share the burden of household budget. Borjas (2008) had developed a model based on Neo Classical theory of leisure labour choice and recognized the workers' decision about hours of work. More working hours means more wages and income to lessen the family financial burden.

Gjerdingen et. al (2001), Erlandson and Eklund (2004) discussed women's health related issues and their nature of work. Studies like Xu et. al (2004), Melchior (2007), Chaudhary et. al (2010) Lu (2011) and Leineweber et. al (2012) investigated the issues of job stress, family issues, depression and anxiety in young working female. Occupational health and safety of women workers and other socioeconomic problem related to women's work participation. Faridi et. al (2009, 2011) explained the factors that motivated to females for work participation and income earnings activities. Khan and Khan (2009) analyzed the females efforts for family survival in urban informal sectors. Moreover, it is found in the literature that women's work participation in different employment status and involvement in earning activities were subject to various human capital formation, socio-demographic and economic factors [Ibrahim (2014), Shaheen et. al (2015), Hina (2015) and Kumar (2016)].

Kabir N. (2017) explored the economic issues of women's empowerment and active citizen ship in Bangladesh and focused on the females' access to economic resources. The study concluded that the membership of microfinance group played an important role in women's empowerment by increasing their income and reducing pressure on men through contributing in family budget. Kabir Md. S et. al (2019) studied the women's income sources in Rural Bangladesh. They sorted out the factors that influence the income of the rural women after participating in small scale farming activities, their assistance to family and their status as empowered. The study concluded that women's actual participation in agricultural farming no doubt, was not only the main source of income but made them empowered and supporting factor of the family. Hafeez Abida et. al (2020) focused on the women's contribution in reducing urban poverty through informal activities. They have measured the women's contribution in family budget by securing employment in informal sector. Findings showed that the contribution of young females in income rising activities and in family budget was greater.

After a comprehensive discussion of past literature, it is concluded that female labour force participation is inevitable for raising the income of family. Unfortunately, a large proportion of the females are involved in many business and economic activities but their efforts are unrecorded and unestimated. Now-a-day, it is not possible for a single person to meet the need of the family. So, it is necessary to acknowledge the women workforce participation and their efforts for family survival. The 
present study is about the analysis of different factors that are core source of contribution in family budget. The main objective of the research to explore the factors that contribute family budget. The rest of research paper is organized as follows. After the detailed introduction and stating the contribution of previous researchers on the present research, the second section discusses the data sources, methodology and model specification. The third section provides results and discussion. The last section of the article is specified for conclusion and policy recommendations.

\section{Data Sources Methodology and Model Specification}

\subsection{Data Sources}

The present study is based on the primary source of data. The selected area Multan City is the largest city of South Punjab (Pakistan). The socio-economic infrastructure of Multan district generally, Multan City especially is comparatively better than other districts of the South Punjab. It is the city of mixed culture. Multan city is the hub of educational institutions both in public and private sectors. It has a second industrial base, but major source of income is agriculture sector. Female population is considered for field survey. Simple random sampling technique is employed to collect the data by wellorganized survey through questionnaire. Various socio-economic factors that may contribute in the family budget are discussed in the questionnaire. The basic education level of the women is considered primary. Almost 400 working women's are selected randomly for survey.

\subsection{Methodology}

Based on the nature of the data, the appropriate estimation technique is ordinary least square method, because the dependent variable is quantifiable. The multivariate regression analysis technique is used to estimate the correlates. The general form of the multiple regressions is:

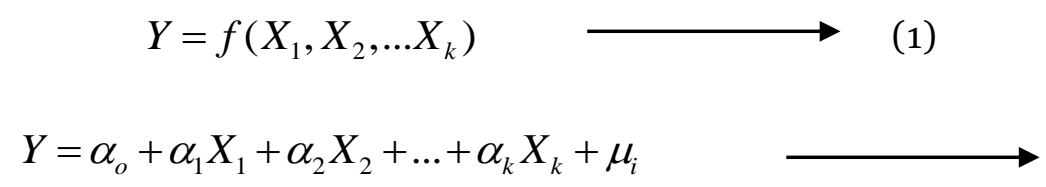

Where $\mathrm{Y}$ is dependent variable $\alpha_{o}$ is the intercept term and $\alpha_{1}, \alpha_{2}, \ldots, \alpha_{k}$ are the partial regression coefficients. The variables $X_{1}, X_{2}, \ldots X_{k}$ are called explanatory variables $\mu_{i}$ is a stochastic disturbance term and satisfy all the OLS assumptions.

\subsection{Specified Models and definitions of the variables}

The general form of the operational model is given below

$$
\begin{aligned}
W C B=f & \left(A G E, A G E^{2}, T E D, P O W, R S D, W W H, M S T,\right. \\
& A H D, M E H, N C H, H P I, H P T, W W K, N H D, F M S, \longrightarrow \\
& \text { NOD, HSZ,OFW, PED, SED, BED, MED, HED })
\end{aligned}
$$

All these variables determine women's contribution in family budget. Equation 3 explains only general form. Now we report the specific forms of the operational model. The second and third models explain the women's contribution in the family budget by considering the age profile of the respondent and education levels with other socio-economic variables. The model-I considers the complete year of age and completed year of education of the respondent. 
Model - I

$$
\begin{aligned}
W C B= & \alpha_{o}+\alpha_{1} A G E+\alpha_{2} A G E^{2}+\alpha_{3} T E D+\alpha_{4} O F W+\alpha_{5} M S T+\alpha_{6} R S D+\alpha_{7} W W H \\
& +\alpha_{8} H S Z+\alpha_{9} A H D+\alpha_{10} M E H+\alpha_{11} P O W+\alpha_{12} N C H+\alpha_{13} H P I+\alpha_{14} W O H+\mu_{i}
\end{aligned}
$$

In the model 3, we have introduced the various age groups instead of completed year of age in order to explain females' support to family regarding different age groups considering Age 3 as the reference category.

Model - II

$$
\begin{aligned}
W C B= & \gamma_{o}+\gamma_{1} A G E_{1}+\gamma_{2} A E_{2}+\gamma_{3} A G E_{4}+\gamma_{4} A G E_{5}+\gamma_{5} T E D \\
& +\gamma_{6} O F W+\gamma_{7} R S D+\gamma_{8} W W H+\gamma_{9} H S Z+\gamma_{10} A H D+\gamma_{11} M E H \\
& +\gamma_{12} P O W+\gamma_{13} N C H+\gamma_{14} H P I+\gamma_{15} H P T+\gamma_{16} F M S+V_{i}
\end{aligned}
$$

In order to evaluate the contribution of women's various level of education in family budget, we have used dummies of different level of education in our model less than 5 year of education is taken as base category

\section{Model - III}

$$
\begin{aligned}
W C B= & a_{o}+a_{1} A G E+a_{2} P E D+a_{3} S E D+a_{4} B E D+a_{5} M E D+a_{6} H E D+a_{7} R S D \\
& +a_{8} W W H+a_{9} H S Z+a_{10} A H D+a_{11} P O W+a_{12} H P I+a_{13} H P T+a_{14} N H D \\
& +a_{15} N O D+\omega_{i}
\end{aligned}
$$

Now, we provide the description of the variables used in the above specified model and their expected signs are given in table 1.

\section{Table 1: Variables, their Description and Expected hypothesis}

\begin{tabular}{|l|l|c|}
\hline Variable & Description & Expected Signs \\
\hline WCB & $\begin{array}{l}\text { Women's contribution. It is measured as ratio of women's monthly income } \\
\text { to the total household monthly income }\end{array}$ & - \\
\hline AGE & Women's age in completed years & Positive \\
\hline TED & Women's completed years of education & Positive \\
\hline OFW & $\begin{array}{l}\text { It is binary variable. } 1 \text { if the other member in the family is working. o } \\
\text { otherwise }\end{array}$ & Negative \\
\hline MST & It is qualitative variable. 1 if one is married and o otherwise & Negative \\
\hline RSD & $\begin{array}{l}\text { It is dummy variable. It captures the effect of region of residence. } 1 \text { if } \\
\text { women belong to rural area, o otherwise }\end{array}$ & Positive \\
\hline WWH & Women working hour per day & Negative \\
\hline HSZ & Household size. Total number of persons living at home. & Negative \\
\hline AHD & $\begin{array}{l}\text { unavailability of healthy diet. 1 if the women is given good and Healthy } \\
\text { diet. } \text { o otherwise. }\end{array}$ & \\
\hline MEH & Women's monthly expenditure on Health & Negative \\
\hline
\end{tabular}




\begin{tabular}{|c|c|c|}
\hline POW & $\begin{array}{l}\text { Outside work permission. " } 1 \text { " if the women have no permission to work } \\
\text { outside, "o" otherwise. }\end{array}$ & Negative \\
\hline HPI & Household per-capita income & Negative \\
\hline HPT & $\begin{array}{l}\text { Household property holding. } 1 \text { if household women have property. } \\
\text { o otherwise }\end{array}$ & Negative \\
\hline NHD & Health center distance nearest to Home. It measured in Kilo meters & Positive \\
\hline WHO & Women own House & Positive \\
\hline NOD & Number of dependents & Positive \\
\hline PED & Primary level of education. 1 if women is primary educated, o otherwise & Negative \\
\hline SED & $\begin{array}{l}\text { Secondary level of education. } 1 \text { if women is educated up to secondary level, } \\
\text { o otherwise }\end{array}$ & Negative \\
\hline BED & $\begin{array}{l}\text { Bachelor level of education. } 1 \text { if women is educated up to bachelor level, } \\
\text { o otherwise }\end{array}$ & Negative \\
\hline MED & $\begin{array}{l}\text { Masters level of education. } 1 \text { if women is educated up to Masters level, } \\
\text { o otherwise }\end{array}$ & Negative \\
\hline HED & $\begin{array}{l}\text { Higher level of education. } 1 \text { if women is educated up to higher level, } \\
\text { o otherwise }\end{array}$ & Negative \\
\hline $\mathrm{NCH}$ & No. of Children. & Positive \\
\hline
\end{tabular}

\section{Results and Discussion}

We explain the findings of the study relating to all specified model. Table 2 provides the discussion of the factors that highlight the women's contribution to family budget.

Table 2: OLS Estimates of the Model-I

\begin{tabular}{|c|c|c|c|}
\hline Variable & Coefficients & Std.Error & t-Statistics \\
\hline AGE & $0.0158^{* * *}$ & 0.0095 & 1.66 \\
\hline AGE $^{2}$ & $-0.0002^{* *}$ & 0.0001 & 4.00 \\
\hline TED & $0.018^{*}$ & 0.0045 & -0.98 \\
\hline OFW & $-0.044^{*}$ & 0.0451 & -1.71 \\
\hline MST & $-0.0768^{* *}$ & 0.0450 & -1.78 \\
\hline RSD & $-0.0727^{* *}$ & 0.0408 & 0.81 \\
\hline WWH & 0.0035 & 0.0043 & -2.28 \\
\hline HSZ & $-0.0157^{*}$ & 0.0069 & 0.55 \\
\hline AHD & -0.0167 & 0.0302 & -0.579 \\
\hline MEH & $-3.67 \mathrm{E}^{-06}$ & $6.34 \mathrm{E}^{-06}$ & -2.29 \\
\hline POW & $-0.0691^{* *}$ & 0.0302 & 1.04 \\
\hline NCH & 0.0119 & 0.0114 & -0.7431 \\
\hline HPI & $-6.90 E^{-07}$ & $9.29 \mathrm{E}$ & 0.42 \\
\hline WOH & 0.0120 & 0.0284 & 0.32 \\
\hline $\mathrm{C}$ & 0.0578 & 0.1831 & 4.326 \\
\hline $\mathrm{R}^{2}$ & 0.136 & F- Statistics & 0.000 \\
\hline Adj R & 0.105 & Prob (F-Statistics) & \\
\hline Size of Sample & 400 & & \\
\hline
\end{tabular}

* significance at $1 \%$ level

** significance at $5 \%$ level

$* * *$ significance at $10 \%$ level 
The overall significance of the model is gauged by the value of F-statistic that is highly significant at one percent level of significance. The value of Coefficient of determination $\mathrm{R}^{2}$ is low (o.14). Generally, in Cross-sectional data analysis the value of $\mathrm{R}^{2}$ and adjusted $\mathrm{R}^{2}$ is low, which does not matter.

We have observed that the Coefficient of AGE is positive and marginally significant. The women's contribution in family budget is increased about 0.016 units due to an increase of one year of women's age. The AGE square has a negative impact on the family budget and is very significant. The reason may be that as the women has reached the prime age, her working efficiency falls and income reduces. These findings are matched with the studies of Hafeez and Ahmad (2007) and Goksel (2013).

Women's education has turned out be very significant factor regarding their contribution in family income. The Coefficient of Total Years of Education (TED) 0.018. Educated Women's struggle for family survival is encouraged. Our results are consistent with the findings of Khan and Khan (2007), (2008) and (2009). Other family worker in the household has discouraged the women's efforts for family. The coefficient of other family worker (OFW) is not only negative but insignificant. It is noted in the present study that the married women reduce their share in family income. The Coefficient of marital status (MST) is 0.0768 and statistically significant at 10 percent level. Married women's contribution in family income decreases about 0.768 units.

The Coefficient of region of residence is negative and significant at 10 percent level of significance. The women's belongs to rural area have less contribution as compared to urban area's women. The reason may be that in urban area, there are more jobs opportunities and friendly working atmosphere.

It is also discovered in the present study that women's working hours enhance the women's share to family budget. But it is not so important the present analysis. Household size (HSZ) has negative and highly significant impact on the women's efforts for family survival. The Coefficient of HSZ is -0.0157. The reason may be that the women's households' activities which are unrecognized become very vital as compared to workforce participation. The variables like unavailability of healthy diets (AHD) and women's monthly expenditures on health are not only obstacles in the way of women's efforts for family survival but have insignificant influence. The Coefficient of no permission outside (POW) is -0.0691 and is highly significant at one percent level. The women's share to family income reduces about 0.0691 points because of no permission to one female to work outside the home. The reason may be that the women face many problems and purdah observing females cannot work outside home.

It is noted in the present research that the number of children and women's own house have positive and insignificant influence on females struggle for family survival. Household's Per Capita income has inversely related to women's contribution to family. The coefficient of HPI is negative and statistically insignificant. 
Table 3: OLS Estimates of Model 2

\begin{tabular}{|c|c|c|c|}
\hline Variables & Coefficients & Std.Error & t-statistic \\
\hline AGE-1 & $-0.167^{*}$ & 0.0519 & -3.21 \\
\hline AGE-2 & $-0.099^{*}$ & 0.0409 & -2.42 \\
\hline AGE-4 & 0.26 & 0.044 & 0.59 \\
\hline AGE-5 & $0.1575^{*}$ & 0.0511 & 3.08 \\
\hline TED & $0.0199^{*}$ & 0.0045 & 4.42 \\
\hline OFW & -0.037 & 0.045 & -0.82 \\
\hline RSD & $-0.075^{* * *}$ & 0.039 & -1.92 \\
\hline WWH & 0.0046 & 0.0042 & 1.06 \\
\hline HSZ & $-0.0154^{* *}$ & 0.0076 & 2.03 \\
\hline AHD & -0.0055 & 0.0302 & -0.18 \\
\hline MEH & $-5.73 E^{-06}$ & $6.30 E^{-06}$ & -0.91 \\
\hline POW & -0.057 & 0.030 & -1.90 \\
\hline NCH & 0.0096 & 0.0116 & 0.83 \\
\hline HPI & $-5.79 E^{-07}$ & $9.23 E^{-07}$ & -0.63 \\
\hline HPT & $-0.1202^{* * *}$ & 0.0656 & -1.83 \\
\hline FMS & -0.0191 & 0.029 & -0.65 \\
\hline C & $0.586^{*}$ & 0.119 & 4.92 \\
\hline $\mathrm{R}^{2}$ & 0.16 & F Statistics & 4.273 \\
\hline Adj R & 0.12 & Prob. (F-statistics) & 4.273 \\
\hline Sample size & 400 & & \\
\hline
\end{tabular}

** significance at $1 \%$ level

** Significance at $5 \%$ level

$* * *$ Significance at $10 \%$ level

Table 3 discuss the findings of model 2 in which different age groups are taken as explanatory variables in lui of completed years of age, in order to examine the contribution of women's in family income regarding the age profile of women. Other socioeconomic variables are almost same as discussed in the model 1. The overall model is highly significant with low explanatory power. Age1 and Age2 belong to the age groups $(15-24)$ and $(25-34)$ respectively. The findings show that women in the both groups have negative influence on family budget.

The Coefficients of both age groups are negative and highly significant at on percent level of significance. The reason may be that the women in early age groups are in learning process and are not working or may be married and have to fulfil child caring responsibilities. Moreover it is noted that the return to age has positive trend. Women's share to family budget is continuously increasing in the upper age cohorts AGE4 (45-54) and AGE5 (55-64). The coefficients of AGE4 and AGE5 are 0.026 and 0.1575 respectively. The women's belongs to AGE4 and AGE5 are contributing more as compared to AGE3 (35-44) which is bench mark age category. 
Table 4 OLS Estimates of Model-3

\begin{tabular}{|c|c|c|c|}
\hline Variable & Coefficient & Std. Error & t-Statistic \\
\hline AGE & $0.0073^{*}$ & 0.0012 & 6.08 \\
\hline PED & $-0.2055^{*}$ & 0.0645 & -316 \\
\hline SED & 0.00024 & 0.0519 & 0.005 \\
\hline BED & 0.0338 & 0.0443 & 0.763 \\
\hline MED & 0.0395 & 0.0424 & 0.932 \\
\hline HED & 0.0855 & 0.0543 & 1.575 \\
\hline RSD & $-0.0992^{*}$ & 0.0411 & -2.414 \\
\hline WWH & 0.0039 & 0.0042 & 0.929 \\
\hline HSZ & $-0.0119^{* *}$ & 0.006 & -1.98 \\
\hline AHD & -0.0300 & 0.0289 & -1.038 \\
\hline POW & $-0.0679^{*}$ & 0.0298 & -2.279 \\
\hline HPI & $-1.10 E-060$ & $8.35 E-07$ & -1.32 \\
\hline HPT & $-0.1295^{*}$ & 0.0656 & -1.97 \\
\hline NHD & -0.0033 & 0.0031 & -1.065 \\
\hline NOD & 0.0097 & 0.0127 & 0.764 \\
\hline C & $0.4988^{*}$ & 0.1005 & 4.963 \\
\hline R $^{2}$ & 0.142 & F-statistics & 4.2339 \\
\hline Adj. R & 0.109 & Prob. (F-Statistics) & 0.000 \\
\hline Sample size & 400 & & \\
\hline
\end{tabular}

**Significance at $1 \%$ level

** Significance at $5 \%$ level

*** Significance at 10\% level

Table 4 explains the findings of the model 3 which trace out the returns to women's education in household family budget. We have observed that all other variables in the model report the almost same results and their role in sustaining the family is like as in earlier discussed the model. Uneducated females and educated less than five years are taken as base category education. The elementary level of education has negative influence on family budget. Women's educated up to primary level decrease their share in family budget about 0.21 units. The Coefficients of Primary education (PED) is highly significant. The reason may be that the low educated women are unable to secure the jobs. Moreover, it is observed that returns to education have positive trend with increasing return. The highly educated women like M.Phil, PhD degree holders are contribution more in family budget as compared to master degree holders' women. Secondary school certificate holders' women are contributing less than the bachelor's degree holders' women.

\section{Conclusions}

The present study is about women's role for survival of their families. It is based on the primary source of data. The only females respondents are interviewed. Certain socio-economic aspects of women are studied and analyzed in order to examine their contribution for family survival. The research has framed three models for analysis the women's contribution. Overall model considers completed age and completed years of education with other socio-economic variables. The model 2 and model 3 evaluate the impact of various age-groups and various education levels respectively. The study concludes that matured aged and highly educated women's role is observed more effective and responsible for family survival. Moreover, marital status, region of residence, household size, healthy 
diet and women's work per mission are very important factors that play very important role for making families financially more strong.

Following policies are suggested based on the findings of the present research.

- Women's education is very important. Government should provide the educational facilities especially higher education. Technical education for women should be encouraged.

- Family planning is necessary to balance the household size.

- Healthy diet for females is very important.

- Work permission out side the home should be applicable by the society and friendly atmosphere should be provided at the work place.

- Rural areas should be provided facilities at par given urban areas.

\section{References}

Ali, H. (2015), Impact of human capital formation on development: Women Education as an Investment. The International Journal of Humanities and Social Studies 387-393.

Bashir, F., Farooq, S., Nawaz, S., Bagum, M., Sandila, M. A., \& Arshad, M. R. (2012). Education, health and employment in Pakistan: a co-integration analysis. Res. Humanit. Soc. Sci, 2(5), 53-64.

Becker, G. S. (1962). Irrational behavior and economic theory. Journal of political economy, 70(1), 1-13.

Behrman, J. R., \& Wolfe, B. L. (1989). Does more schooling make women better nourished and healthier? Adult sibling random and fixed effects estimates for Nicaragua. Journal of human resources, 644-663.

Chaudhry, I. S., Faridi, M. Z., \& Anjum, S. (2010). The Effects of Health and Education on Female Earnings: Empirical Evidence from District Vehari. Pakistan Journal of Social Sciences (PJSS), 30(1), 109-124.

Erlandsson, L. K., \& Eklund, M. (2004). The relationships of hassles and uplifts to experience of health in working women. Women \& health, 38(4), 19-37.

Faridi, M. Z. (2011). Women's Efforts for Family Subsistence: A Rural Study. Pakistan Journal of Social Sciences (PJSS), 31(2), 319-330.

Faridi, M. Z., Chaudhry, I. S., \& Anwar, M. (2009). The socio-economic and demographic determinants of women work participation in Pakistan: evidence from Bahawalpur District. 24(2), 351-367

Faridi, M. Z., Chaudhry, I. S., \& Malik, M. S. (2011). Why Women are Self-Employed? Empirical Evidence from Pakistan. International Journal of Economics and Finance, 3(1), 198-207.

Faridi, M. Z., Malik, S., \& Basit, A. B. (2009). Impact of Education on Female Labour Force Participation in Pakistan: Empirical Evidence from Primary Data Analysis. Pakistan Journal of Social Sciences (PJSS), 29(1) 127-140.

Gjerdingen, D., McGovern, P., Bekker, M., Lundberg, U., \& Willemsen, T. (2001). Women's work roles and their impact on health, well-being, and career: comparisons between the United States, Sweden, and The Netherlands. Women \& health, 31(4), 1-20.

Göksel, İ. (2013, November). Female labor force participation in Turkey: The role of conservatism. In Women's Studies International Forum Pergamon. 41, 45-54.

Hafeez, A., Shaikh, S. S., \& Qureshi, Z. A. (2020). Measuring female contribution in urban poverty reduction: A perspective from informal sector. International Research Journal of Arts and Humanities (IRJAH), 48(48), 137-153.

Ibrahim, S. A., Scott, F. E., Cole, D. C., Shannon, H. S., \& Eyles, J. (2001). Job strain and self-reported health among working women and men: an analysis of the 1994/5 Canadian National Population Health Survey. Women \& health, 33(1-2), 105-124.

Kabeer, N. (2017). Economic pathways to women's empowerment and active citizenship: What does the 
evidence from Bangladesh tell us?. The Journal of Development Studies, 53(5), 649-663.

Kabir, M., Radović Marković, M., \& Radulović, D. (2019). The determinants of income of rural women in Bangladesh. Sustainability, 11(20), 5842.

Khadim, Z., \& Akram, W. (2013). Female labor force participation in formal sector: An empirical evidence from PSLM (2007-08). Middle-East Journal of Scientific Research, 14(11), 1480-1488.

Khan, R. E. A., \& Khan, T. (2007). Informally Employed Women: Their Characteristics and Contribution in Household Budget. Journal of Applied Sciences, 7(14), 1901-1907.

Khan, T., \& Khan, R. E. A. (2008). Household Characteristics: How much They Affect Women's Contribution in Household Budget. Indian Journal of Labour Economics.

Khan, T., \& Khan, R. E. A. (2009). Urban informal sector: How much women are struggling for family survival. The Pakistan Development Review, 67-95, 48:1.

Khandker, S. R. (1990). Labor market participation, returns to education, and male-female wage differences in Peru (Vol. 461). World Bank Publications.

Leineweber, C., Baltzer, M., Magnusson Hanson, L. L., \& Westerlund, H. (2012). Work-family conflict and health in Swedish working women and men: a 2-year prospective analysis (the SLOSH study). The European Journal of Public Health, 23(4), 710-716.

Lu, J. L. (2011). Occupational health and safety of women workers: viewed in the light of labor regulations. Journal of International Women's Studies, 12(1), 68-78.

Melchior, M., Caspi, A., Milne, B. J., Danese, A., Poulton, R., \& Moffitt, T. E. (2007). Work stress precipitates depression and anxiety in young, working women and men. Psychological medicine, 37(8), 1119-1129.

Mincer, J. (1974). Progress in Human Capital Analysis of the distribution of earnings (No. woo53). Cambridge, Mass., USA: National Bureau of Economic Research.

Mincer, J. (1974). Schooling, Experience, and Earnings. Human Behavior \& Social Institutions No. 2.

Paquette, M. C., \& Raine, K. (2004). Sociocultural context of women's body image. Social science \& medicine, 59(5), 1047-1058.

Pathmanathan, I., \& Liljestrand, J. (Eds.). (2003). Investing in maternal health: learning from Malaysia and Sri Lanka. World Bank Publications.

Schultz, T. P., \& Mwabu, G. (1998). Labor unions and the distribution of wages and employment in South Africa. ILR Review, 51(4), 680-703.

Shaheen, R., Shabir, G., Faridi, M., Z. and Yasmin, F. (2015). Determinants of Female Employment Status in Pakistan :A Case of Sahiwal District. Journal of Commerce and Social Sciences, 9(2), 418-437.

Tinker, I. (2000). Alleviating poverty: Investing in women's work. Journal of the American planning association, 66(3), 229-242.

$\mathrm{Xu}$, et al(2004). Measuring job stress and family stress in Chinese working women: a validation study focusing on blood pressure and psychosomatic symptoms. Women \& health, 39(2), 31-46. 